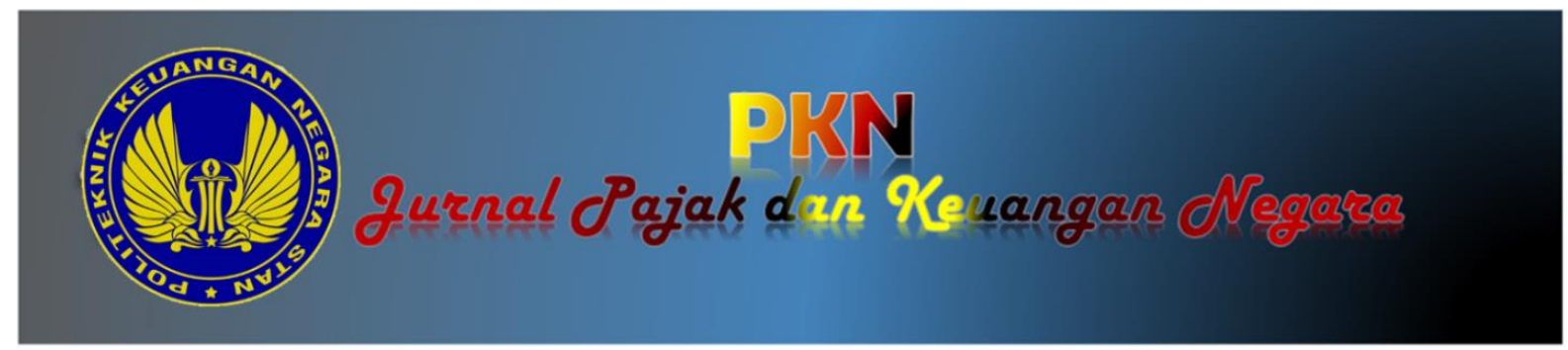

\title{
PENGARUH STRUKTUR KEPEMILIKAN PERUSAHAAN TERHADAP TAX AVOIDANCE DI INDONESIA DENGAN CORPORATE GOVERNANCE SEBAGAI VARIABEL MODERASI
}

\author{
Toto Andriyanto \\ Politeknik Keuangan Negara STAN \\ Andri Marfiana \\ Politeknik Keuangan Negara STAN
}

Alamat Korespondensi: andri.marfiana@pknstan.ac.id

INFORMASI ARTIKEL
Diterima Pertama
[02 06 2021]
Dinyatakan Diterima
[2506 2021]
KATA KUNCI:
Corporate governance, struktur
kepemilikan, multiple large
shareholders, tax avoidance.

KLASIFIKASI JEL:

$\mathrm{H} 26$

\begin{abstract}
Tax avoidance is a strategy that companies can take to reduce their tax payments. The purpose of this study is to look at the effects of family, foreign, and government ownership on tax avoidance. This study also tries to identify the effect of corporate governance on tax avoidance by companies with family, foreign, and government ownership. Corporate governance is seen from the existence of multiple large shareholders (MLS), independent commissioners, and audit quality by BIG 4affiliated public accounting firms. Tax avoidance is measured using the effective tax ratio (ETR) and book tax different (BTD). The population of this study is a company listed on the Indonesia Stock Exchange for the period 2017-2019. The research sample was selected using purposive sampling technique which resulted in 141 companies for analysis. The results of this study indicate that family, foreign, and government ownership have a positive effect on tax avoidance. The existence of $M L S$ in companies with family and foreign ownership causes a negative effect on tax avoidance. The existence of auditors from KAP Big 4 does not reduce the possibility of companies with family, foreign and government ownership involved in tax avoidance practices. Meanwhile, the existence of independent commissioners does not have a significant effect on the relationship between family, foreign, and government ownership on tax avoidance. This study also shows that there is a relationship between agency theory and legitimacy theory with tax avoidance, both positively and negatively according to the variables tested.
\end{abstract}

\section{ABSTRAK}

Tax avoidance merupakan salah satu strategi yang dapat dilakukan perusahaan untuk mengurangi pembayaran pajaknya. Penelitian ini mencoba untuk melihat efek dari kepemilikan keluarga, asing, dan pemerintah terhadap tax avoidance. Penelitian ini juga mencoba untuk mengidentifikasi pengaruh dari corporate governance terhadap tax avoidance yang dilakukan oleh perusahaan dengan kepemilikan keluarga, asing, dan pemerintah. Populasi dari penelitian ini merupakan perusahaan selain sektor keuangan dan properti yang terdaftar di Bursa Efek Indonesia periode 2017-2019. Sampel penelitian dipilih menggunakan teknik purposive sampling yang menghasilkan 141 perusahaan untuk dianalisis. Hasil dari penelitian ini menunjukan bahwa kepemilikan keluarga, asing, maupun pemerintah berpengaruh positif terhadap tax avoidance. Keberadaan MLS dalam perusahaan dengan kepemilikan keluarga dan asing membuat pengaruhnya terhadap tax avoidance menjadi negatif. Keberadaan auditor dari KAP Big 4 tidak menurunkan kemungkinan perusahaan dengan kepemilikan keluarga, asing, dan pemerintah terlibat dalam praktik tax avoidance. Sedangkan keberadaan dari komisaris independen tidak memberikan pengaruh signifikan dalam hubungan antara kepemilikan keluarga, asing, dan pemerintah terhadap tax avoidance. Penelitian ini juga menunjukan bahwa terdapat hubungan antara teori agensi dan teori legitimasi dengan tax avoidance., baik secara positif maupun negatif sesuai variabel yang diuji. 


\section{PENDAHULUAN}

\subsection{Latar Belakang}

Tax avoidance merupakan salah satu upaya perusahaan untuk mengurangi nilai pembayaran pajaknya (Gaaya et al, 2017). Perilaku tax avoidance dapat mendatangkan beberapa keuntungan bagi perusahaan diantaranya peningkatan profitabilitas dan penurunan beban dari perusahaan (Rusydi dan Martani, 2014). Pemegang saham perusahaan dan manajemen dianggap sebagai pihak yang diuntungkan dengan adanya perilaku tax avoidance. Keuntungan yang didapatkan oleh pemegang saham perusahaan dapat berupa kenaikan penerimaan dividen dari perusahaan. Bagi manajemen, keuntungan paling umum dari adanya perilaku tax avoidance adalah peningkatan bonus kinerja akibat adanya peningkatan laba perusahaan.

Praktik tax avoidance yang dilakukan perusahaan juga memberikan beberapa resiko bagi perusahaan. Resiko yang paling jelas terlihat adalah adanya resiko perusahaan untuk dikenakan sanksi dan denda oleh otoritas pajak (Rusydi dan Martani, 2014). Pemegang saham dapat kehilangan kekayaannya dengan adanya resiko penurunan nilai saham dan juga resiko reputasi mereka tercoreng (Hanlon dan Slemrod, 2009). Manajemen dapat kehilangan pekerjaannya dan adanya resiko rusaknya reputasi yang akan menyulitkan mereka di kemudian hari (Kovermann dan Velte, 2019). Oleh karena itu, manajemen merupakan pihak yang cenderung untuk menghindari resiko (Kovermann dan Velte, 2019). Mereka hanya akan melakukan perilaku tax avoidance apabila itu sejalan dengan kepentingannya ataupun pemegang saham.

Manajemen merupakan pihak yang dapat menentukan sejauh mana keterlibatan perusahaan dalam tindakan tax avoidance (Kovermann dan Velte, 2019). Keputusan manajemen untuk melakukan tax avoidance salah satunya dipengaruhi oleh jenis struktur kepemilikan dari perusahaan. Struktur kepemilikan perusahaan terbagi menjadi dua yaitu struktur kepemilikan tersebar dan struktur kepemilikan terpusat (Morck et al, 1988 dalam Heflin dan Shaw, 2000). Pada perusahaan dengan kepemilikan tersebar, konflik keagenan lebih banyak terjadi antara manajemen dan pemegang saham (Kovermann dan Wendt, 2019). Manajemen memiliki lebih banyak kebebasan dalam menentukan kebijakan perusahaan. Hal ini pemegang saham tidak menaruh perhatian khusus pada satu perusahaan, karena mereka tidak memiliki sumber daya yang cukup atau insentif untuk memantau dengan cermat semua investasi mereka (Fama, 1980). Sebaliknya, pada struktur kepemilikan terpusat, pemisahan antara kontrol dan kepemilikan sangat tipis karena pemegang saham utama (pemilik) memiliki insentif yang kuat untuk mengawasi perusahaan (Shleifer dan Vishny, 1986). Pemilik saham mayoritas memiliki kewenangan yang lebih besar untuk mengatur operasi perusahaan, seperti pemilihan
CEO dan direktur (Jiang et al, 2010). Hal ini membuat peran dari pemilik utama lebih besar daripada manajemen dan manajer dapat diganti jika mereka tidak memberikan hasil yang diinginkan (Kovermann dan Wendt, 2019).

Struktur kepemilikan terkonsentrasi lebih banyak ditemui dalam ekonomi global (La Porta dan Shleifer, 1999 dalam Ouyang et al, 2020), termasuk di Indonesia. Struktur kepemilikan di Indonesia yang memiliki sebaran sebanyak $73 \%$ berupa struktur kepemilikan keluarga dan 9\% berupa kepemilikan pemerintah (Claessens, 2002). Dapat dikatakan bahwa pemilik perusahaan memegang peranan penting dalam keputusan perusahaan, termasuk untuk terlibat dalam praktik tax avoidance di Indonesia. Beberapa penelitian telah dilakukan untuk mengetahui pengaruh struktur kepemilikan terhadap perilaku tax avoidance. Di Indonesia terdapat penelitian yang dilakukan oleh Rusydi dan Martani (2014), dan Septiya dan Novita (2018) yang membagi struktur kepemilikan di Indonesia menjadi struktur kepemilikan keluarga, asing, dan pemerintah. Berbagai penelitian serupa juga terdapat di negara lain seperti penelitian Chen et al (2010) dan Gaaya et al (2017) tentang kepemilikan keluarga, Salihu et al (2015) tentang kepemilikan asing, dan Bradshaw et al (2019) tentang kepemilikan pemerintah. Namun beberapa penelitian yang telah dilakukan masih memberikan hasil yang berbeda-beda sehingga penulis merasa penelitian di bidang ini masih perlu dilakukan untuk menemukan hasil yang terbaik.

Dari data Claessens, kepemilikan keluarga memiliki jumlah yang lebih banyak dibanding jenis kepemilikan lain dari total kepemilikan perusahaan di Indonesia. Keberadaan kepemilikan keluarga dalam perusahaan cenderung dapat mengatasi masalah keganenan antara manajemen dan pemilik (Chen et al, 2010). Perusahaan dengan kepemilikan keluarga cenderung enggan reputasinya tercoret apabila dimasa depan diketahui adanya perilaku tax avoidance melalui pemeriksaan oleh otoritas pajak (Rusydi dan Martani, 2014). Pendapat berlainan diungkapkan Gaaya et al (2017) bahwa perusahaan keluarga memiliki peluang yang besar untuk melakukan perilaku tax avoidance dan mengalihkan kekayaan perusahaan menjadi milik pribadinya. Pertimbangan atau trade off antara peluang memperoleh kekayaan dari tax avoidance dan pertimbangan resiko dan biaya lebih besar terjadi pada perusahaan dengan kepemilikan keluarga dibanding non keluarga (Gaaya et al, 2017).

Jenis kepemilikan lainnya yang memegang porsi cukup banyak di Indonesia menurut Claessens adalah kepemilikan dari pemerintah, yang biasanya tercermin dalam Badan Usaha Milik Negara atau Daerah (BUMN/BUMD). Perusahaan pemerintah memiliki kontribusi pendapatan bagi pemerintah melalui dua saluran yaitu pajak dan dividen. Konflik keagenan antara pemilik utama dengan pemilik saham minoritas pada perusahaan dengan kepemilikan pemerintah cukup unik. Ketika pemilik utama perusahaan mengambil kekayaan dari pemegang saham minoritas, yang diuntungkan adalah pihak pemerintah. Oleh 
karena itu, pembayaran pajak yang tinggi dari perusahaan dengan kepemilikan pemerintah akan menguntungkan bagi negara namun kurang menguntungkan bagi pemegang saham minoritas (Bradshaw et al, 2019). Pembayaran pajak yang lebih banyak kepada pemerintah memang selaras dengan kepentingan pemerintah, namun perusahaan dengan kepemilikan pemerintah memiliki insentif untuk menaikan laba dan menurunkan pembayaran pajak sehingga bisa memiliki lebih banyak sumber daya (Tang dan Firth, 2011). Meskipun sama-sama pihak pemerintah, uang yang digunakan untuk pembayaran pajak tidak dapat digunakan langsung oleh perusahaan, melainkan akan digunakan pihak pemerintah untuk membiayai kebutuhan masyarakat (Tang, 2016).

Struktur kepemilikan lainnya yang cukup dominan di Indonesia adalah struktur kepemilikan asing (Martani dan Rusydi, 2014). Badan Koordinasi Penanaman Modal (BKPM) menyebutkan bahwa realisasi foreign direct investment (FDI) di Indonesia pada 10 tahun terakhir mengalami peningkatan yang signifikan. Di kuarter IV tahun 2010, realisasi FDI Indonesia berada dibawah angka 40 triliun rupiah namun pada akhir kuarter IV tahun 2019, realisasi nya sudah menyentuh angka 105,3 triliun rupiah. Peningkatan investasi dari pihak asing merupakan suatu capaian yang bagus dalam upaya meningkatkan pertumbuhan ekonomi nasional (Salihu et al, 2015). Tapi dalam kaitannya dengan pajak, Christensen dan Murphy (2004) memiliki pandangan lain. Christensen dan Murphy (2004) berpendapat bahwa perusahaan multinasional telah menyusun strategi bisnisnya dengan cara untuk menghindari pajak di berbagai negara. Hal ini mungkin dikarenakan adanya peluang untuk melakukan profit shifting (Shackelford dan Sheflin, 2001) dan adanya insentif pajak di negara asalnya (Salihu et al, 2015). Hal yang sedikit berbeda diungkapkan oleh Khanna dan Palepu (2000) dalam Rusydi dan Martani (2014) yang menyatakan bahwa kepemilikan asing dianggap dapat mendorong perusahaan untuk menerapkan standar corporate governance yang lebih tinggi, sehingga diharapkan dapat mengurangi tindakan tax avoidance.

Salah satu mekanisme yang mempengaruhi perilaku pemegang saham utama maupun manajemen dalam memilih tindakan tax avoidance adalah corporate governance (Kovermann dan Velte, 2019). Corporate governance dapat didefinisikan sebagai kombinasi dari beberapa mekanisme yang menjamin manajemen menjalankan perusahaan untuk kepentingan satu atau beberapa pemangku kepentingan (Georgen \& Renneboog, 2006). Salah satu komponen dari corporate governance yang mempengaruhi keputusan terkait tax avoidance adalah adanya pengawasan yang efektif bagi manajemen dan pemegang saham utama (Kovermann dan Velte, 2019). Pengawasan untuk memperkuat corporate governance dari suatu perusahaan dapat datang dari internal maupun eksternal perusahaan. Pengawasan dari pihak internal dapat dilakukan dewan direksi maupun komisaris, salah satunya dengan keberadaan komisaris independen (Kovermann dan Velte, 2019). Sedangkan pengawasan yang datang dari pihak eksternal dapat dilakukan oleh pemegang saham lain perusahaan, auditor eksternal, pemerintah, dan pemangku kepentingan yang lain (Kovermann dan Velte, 2019). Penelitian ini berfokus pada aspek pengawasan dari pihak internal dengan keberadaan komisaris independen dan pengawasan eksternal oleh pemegang saham dan auditor eksternal perusahaan.

Dewan komisaris dan direksi bertindak sebagai agen dalam perusahaan (Fama \& Jansen, 1983) atau pemegang kuasa pemegang saham dalam mengawasi dan menjalankan perusahaan. Komisaris dalam perusahaan dapat berasal dari perwakilan pemilik, manajemen, ataupun pihak independen. Dalam kaitannya dengan konflik keagenan, komisaris yang berasal dari kalangan independen dapat menjadi alat pengawas tambahan bagi perusahaan (Fama, 1980). Semakin besar proporsi dari komisaris independen dalam sebuah perusahaan, pengawasan kepada manajemen dalam perusahaan akan meningkat yang tentunya akan berguna bagi kepentingan pemegang saham, ataupun masyarakat secara keseluruhan (Lanis dan Richardson, 2011).

Pengawasan terhadap pemegang saham utama dapat dilakukan oleh pemegang saham besar lainnya dalam perusahaan (MLS). Kepemilikan saham menyebar dapat mengurangi masalah asimetri informasi antara manajemen dan pemilik ataupun antar pemilik saham utama dengan pemilik saham minoritas. Keberadaan MLS dapat memberikan keuntungan seperti menciptakan kompetisi antar blockholders (pemegang saham besar) untuk saling mengawasi (Bloch dan Hedge, 2000 dalam Huaili, 2015). Hal ini dapat membuat pemegang saham lain menyeimbangkan kekuatan dengan pemegang saham utama (Bennedsen dan Wolfenzon, 2000); dan juga mencegah pemegang saham utama untuk melakukan perbuatan yang menyimpang (moral hazard) (Berkman et al, 2009).

Auditor eksternal dapat bertindak sebagai pengawas dari pihak eksternal melalui auditnya atas laporan keuangan yang mencangkup item pajak didalamnya (Kovermann dan Velte, 2019). Oleh karena itu, kemampuan dan kualitas auditor dipandang menjadi faktor yang penting dalam kaitannya dengan perilaku tax avoidance. Beberapa literatur membandingkan kualitas auditor antara auditor dari kantor akuntan publik (KAP) Big 4 dan selain Big 4 (Richardson et al, 2013; Kanagaretnam et al, 2016; dan Gaaya et al, 2017). Auditor dari KAP Big 4 dianggap lebih menjaga reputasi dan nama baiknya sehingga hasil auditnya dianggap lebih berkualitas (Gaaya et al, 2017). Namun di Indonesia sendiri, beberapa peneliti 
tidak menemukan hubungan signifikan antara kualitas audit oleh KAP Big 4 dengan kecenderungan perusahaan terlibat dalam tax avoidance (Septiya dan Novita, 2018).

\subsection{Tujuan Penelitian}

Salah satu hal yang mendorong adanya penelitian ini adalah karena perilaku tax avoidance merupakan salah satu ancaman bagi perolehan penerimaan pajak pemerintah. Terlebih lagi terdapat beberapa pengungkapan praktik tax avoidance yang ada di perusahaan besar di Indonesia oleh Direktorat Jenderal Pajak diantaranya kasus Asian Agri, Bumi Resources, Adaro, Indosat, Indofood, dan Kaltim Prima Coal (KPC) (Rusydi dan Martani, 2014). Perusahaan tersebut merupakan perusahaan yang memiliki kepemilikan terkonsentrasi (Rusydi dan Martani, 2014).

Penulis juga mencoba melihat mekanisme corporate governance yang dapat mengurangi kecenderungan untuk terlibat dalam perilaku tax avoidance. Oleh karena itu, penulis menjadikan hal tersebut sebagai dasar penelitian dengan mempertimbangkan faktor struktur kepemilikan perusahaan serta keberadaan corporate governance pada perusahaan di Indonesia.

\section{KERANGKA TEORI}

\subsection{Teori Keagenan (Agency Theory)}

Jensen dan Meckling (1976) mendefinisikan agency theory sebagai sebuah model hirarkis antara principle dan agent, dimana terdapat pendelegasian wewenang oleh principle kepada agent untuk mengambil keputusan dan melaksanakan tugas atas nama principle. Maestrini et al (2018) menyebutkan kondisi ini dapat menyebabkan masalah keagenan (agency problem) yang membuat principle dan agent mempunyai tujuan yang berbeda. Pihak agent tidak lagi bekerja sesuai kepentingan principle (Mahaney dan Laderer, 2003). Masalah keagenan dibagi menjadi dua jenis yaitu masalah keagenan tipe satu (type-one agency problem) dan masalah keagenan tipe dua (type-two agency problem). Masalah keagenan tipe satu terjadi ketika konflik terjadi antara pemilik yang berada diluar perusahaan dengan manajer sebagai pihak yang menjalankan perusahaan (Jensen dan Meckling, 1976). Masalah keagenan tipe satu umumnya terjadi pada perusahaan dengan struktur kepemilikan yang menyebar (Fama dan Jensen, 1983). Sedangkan masalah keagenan tipe dua terjadi ketika terdapat konflik kepentingan antara pemegang saham utama dan pemegang saham minoritas (Claessens, 2000, 2002; Faccio dan Lang, 2002).

\subsection{Legitimacy Theory}

Suchman (1995) menyebutkan bahwa legitimacy merupakan sebuah persepsi atau asumsi bahwa perilaku dari sebuah entitas untuk bisa tepat dan sesuai dengan beberapa sistem norma, nilai, kepercayaan, dan definisi yang dibangun secara sosial. Kata legitimacy seringkali dihubungkan dengan istilah "kontrak sosial" yang menunjukan ekspektasi masyarakat tentang bagaimana seharusnya organisasi beroperasi (Deegan, 2018; Adler et al, 2018).

\subsection{Tax Avoidance}

Secara umum, tax avoidance dapat diartikan sebagai segala sesuatu yang dapat mengurangi pajak perusahaan relatif terhadap pendapatan sebelum pajaknya (Dyreng et al, 2010). Hanlon dan Heitzman (2010) mendefinisikan tax avoidance sebagai pengurangan dari pajak eksplisit (explicit tax). Spektrum dari tax avoidance ini begitu luas dalam berbagai penelitian. Tax avoidance mencangkup berbagai istilah dan kegiatan seperti tax management, tax planning, tax aggressiveness, tax evasion, dan tax sheltering (Huseynov dan Klamm, 2012; Hanlon dan Heitzman, 2010). Pada level yang lebih rendah, tax avoidance merupakan sebuah strategi pajak yang legal (Lisowsky, 2010), seperti memanfaatkan akumulasi rugi pajak (Kovermann dan Wendt, 2019). Di level menengah, tax avoidance mulai dilakukan dengan lebih agresif dengan memanfaatkan celah dan ambiguitas dalam peraturan perpajakan (Kovermann dan Wendt, 2019). Pada level yang lebih tinggi, tax avoidance dapat menjadi sebuah penggelapan pajak yang ilegal (Kovermann dan Wendt, 2019).

Dari sisi teori keagenan, pemegang saham utama dapat menjadikan perilaku tax avoidance sebagai perisai untuk mengalihkan sumber daya dari perusahaan (Desai dan Dharmapala, 2006) seperti melalui transaksi antar pihak berelasi (Ouyang et al, 2020). Tambahan cash flow dari aktivitas tax avoidance dan peningkatan financial opacity dari aktivitas perencanaan pajak dapat meningkatkan insentif pemegang saham utama untuk melakukan aktivitas tunelling (pengalihan sumberdaya perusahaan untuk pemegang saham utama perusahaan) (Bauer et al, 2019).

Ditinjau dari sisi legitimasi, pembayaran pajak perusahaan memiliki implikasi sosial kepada masyarakat. Hal itu dikarenakan pajak dari perusahaan memegang peranan penting dalam mendanai penyediaan berbagai fasilitas kepada masyarakat oleh negara. Tindakan tax avoidance dianggap sebagai tindakan yang tidak sesuai dengan semangat hukum yang mendasarinya (Lanis dan Richardson, 2013). Strategi perusahaan untuk meminimalkan pembayaran secara sengaja dianggap sebagai sesuatu yang tidak etis (Landolf dan Simon, 2008) dan tidak sesuai dengan harapan masyarakat terhadap perusahaan (Christensen dan Murphy, 2004). Tindakan meminimalkan pembayaran pajak melalui tax avoidance dapat menghasilkan kerugian yang signifikan dan berpotensi tidak dapat dipulihkan bagi masyarakat secara keseluruhan (Lanis dan Richardson, 2013). 


\subsection{Struktur Kepemilikan dan Hipotesis Penelitian}

\subsubsection{Kepemilikan Keluarga}

Perusahaan dengan kepemilikan keluarga terjadi ketika pemegang saham utama dari sebuah perusahaan adalah pihak keluarga atau grup perusahaan keluarga (Rusydi dan Martani, 2014). Perusahaan dengan kepemilikan keluarga biasanya memiliki konsentrasi kepemilikan yang tinggi, diversifikasi kebijakan yang lebih rendah, memiliki tujuan jangka panjang, dan kepedulian yang tinggi terhadap reputasi (Chen et al, 2010). Keluarga pemilik biasanya memiliki insentif untuk mempertahankan reputasi dari keluarga karena mereka berniat untuk mempertahankan warisan perusahaan hingga beberapa generasi kedepan, bukan hanya terbatas pada diri mereka (Casson, 1999 dalam Chen et al, 2010). Perusahaan dengan kepemilikan keluarga juga merupakan perusahaan yang peduli akan keberlangsungan dan nilai saham dari perusahaan. Hal ini dikarenakan sebagian besar kekayaan pihak keluarga berada dalam perusahaan (Chen et al, 2010). Keluarga pemilik lebih mementingkan penciptaan nilai di masa depan daripada keuntungan jangka pendek (Gaaya et al, 2017). Hal ini menunjukan bahwa perusahaan dengan kepemilikan keluarga merupakan salah satu alternatif dari corporate governance (Jensen dan Meckling, 1976), dan merupakan salah satu bentuk organisasi yang paling efisien jika dibandingkan dengan perusahaan nonkeluarga (Ang et al, 2000).

Perusahaan dengan kepemilikan keluarga biasanya melibatkan anggota keluarganya untuk menjadi bagian dari dewan direksi maupun komisaris. Penunjukan anggota keluarga sebagai bagian dari dewan direksi maupun komisaris dipengaruhi oleh kepentingan keluarga untuk mempertahankan relevansinya dalam kendali perusahaan (Peng \& Jiang, 2010). Hal ini membuat kontrol dari pihak keluarga dalam perusahaan dengan kepemilikan keluarga begitu besar. Status sebagai pemilik dan pengendali perusahaan kadang tidak dapat dipisahkan pada perusahaan keluarga (Kovermann dan Wendt, 2019). Kondisi ini dapat menimbulkan kemungkinan bahwa pihak keluarga selaku pemilik dan pengendali dapat mengambil keuntungan pribadi dan mengorbankan kepentingan pemegang saham lainnya (Kovermann dan Wendt, 2019). Salah satu cara yang dapat dilakukan adalah melalui tax avoidance yang digunakan untuk menyembunyikan kerugian, menutupi perilaku rent extraction dan mengelabui pemegang saham minoritas (Desai dan Dharmapala, 2006). Sebagai contoh adalah ketika perusahaan melakukan pinjaman berbunga tinggi kepada perusahaan afiliasi untuk menghindari pembayaran pajak yang lebih tinggi (Kovermann dan Wendt, 2019). Selain dapat menghindari pajak, contoh ini juga dapat membuat pembayaran dividen kepada pemegang saham minoritas menjadi lebih kecil.

Berdasarkan teori ini peneliti merumuskan hipotesis sebagai berikut:
H1: Kepemilikan keluarga berpengaruh positif terhadap perilaku tax avoidance.

\subsubsection{Kepemilikan Asing}

Kepemilikan asing bentuknya bermacammacam, seperti investasi langsung, joint ventures, merger dan akuisisi, ataupun kepemilikan modal oleh pihak asing (Dahiya \& Gupta, 2004). Keberadaan dari kepemilikan asing, terutama melalui investasi langsung, banyak diinginkan oleh banyak negara berkembang karena dianggap dapat meningkatkan perekonomian di negara tersebut (Salihu et al, 2015). Hal ini didasari pada berbagai keuntungan adanya kepemilikan asing di suatu negara antara lain peningkatan produktivitas (Khawar, 2003), pengungkapan informasi secara sukarela yang lebih tinggi (Haniffa \& Cooke, 2002), peningkatan good corporate governance perusahaan (Aggarwal et al, 2011), dan tingginya efisiensi dan profitabilitas (D'Souza et al, 2001). Adanya transfer pengetahuan maupun teknologi merupakan sesuatu yang diharapkan oleh negara berkembang tersebut. Chen et al (2014) menyebutkan bahwa kepemilikan pihak asing meningkatkan efisiensi investasi dan membantu mengatasi masalah asimetri informasi dan masalah keagenan. Potensi adanya perampasan kekayaan pemegang saham minoritas oleh pemegang saham utama lebih kecil pada perusahaan yang memiliki kepemilikan asing, karena kuatnya transparansi (Berkman et al, 2010; Anderson et al, 2019).

Di sisi lain, perusahaan dengan kepemilikan asing seringkali terlibat dalam kegiatan tunnelling (Shan, 2013). Kegiatan tunnelling merupakan kegiatan transfer sumberdaya keluar dari perusahaan untuk kepentingan pemegang saham utama (Sugiharto dan Sari, 2014). Transfer sumberdaya dapat melalui transfer langsung (direct shifting) maupun tidak langsung. Transfer langsung dilakukan melalui praktik profit shifting, seperti kegiatan transfer pricing dan pembayaran royalti, yang memanfaatkan kesenjangan dan ketidaksesuaian dalam aturan perpajakan antar negara (Egger, 2010). Sedangkan transfer tidak langsung biasanya dilakukan melalui praktik debt shifting (Egger, 2010).

Sehingga hipotesis yang dibuat adalah:

\section{H2: Kepemilikan asing berpengaruh positif terhadap perilaku tax avoidance.}

\subsubsection{Kepemilikan Pemerintah}

Suatu perusahaan dapat dikatakan memiliki kepemilikan pemerintah apabila proporsi saham perusahaan lebih besar dimiliki oleh pihak pemerintah (Rusydi dan Martani, 2014). Bradshaw et al (2019) menyatakan bahwa efek dari kepemilikan pemerintah kurang lebih sama dengan adanya pengawasan yang ketat dari otoritas pajak yaitu akan menurunkan kemungkinan adanya praktek tax avoidance dan masalah keagenan. Perusahaan dengan kepemilikan pemerintah cenderung dianggap tidak mendukung 
praktik tax avoidance karena pemerintah sebagai pemegang saham lebih memperhatikan tujuan sosial dan politik daripada sekedar keuntungan perusahaan (Tang, 2016). Perusahaan dengan kepemilikan pemerintah akan membayar pajak lebih banyak dibandingkan dengan perusahaan tanpa kepemilikan pemerintah. Hasil serupa diungkapkan oleh Zhang (2012) dalam Rusydi dan Martani (2014) bahwa kepemilikan pemerintah berpengaruh negatif terhadap perilaku tax avoidance.

Pernyataan berbeda diungkapkan oleh Chen et al (2008) dan Fan et al (2007) yang menyatakan bahwa perusahaan dengan kepemilikan pemerintah memiliki tingkat keuntungan dan efisiensi yang rendah, tata kelola yang buruk, serta konflik keagenan yang lebih parah antara pemilik mayoritas dengan minoritas (principle-to-principle) dibandingkan dengan perusahaan tanpa kepemilikan pemerintah. Kerugian yang dialami oleh perusahaan dengan kepemilikan pemerintah terkadang disubsidi oleh pemerintah sehingga membuat mereka kurang memandang fokus dalam penciptaan efisiensi dan nilai perusahaan sebagai sesuatu yang mendesak dan penting (Chen et al, 2008). Selain itu, perusahaan dengan kepemilikan pemerintah memiliki biaya dan resiko yang lebih rendah dalam melakukan praktik tax avoidance karena adanya koneksi politik (Tang, 2016). Potensi penurunan nilai saham juga tidak begitu mempengaruhi mereka karena saham milik pemerintah tidak dapat diperjualbelikan secara bebas di pasar saham. Penurunan harga saham bukanlah merupakan perhatian utama bagi perusahaan yang pemilik utamanya tidak dapat meraih keuntungan dari kenaikan nilai saham (Jiang et al, 2010). berikut:

Hipotesis yang diharapkan adalah sebagai

H3: Kepemilikan pemerintah berpengaruh positif terhadap perilaku tax avoidance.

\subsection{Efek Moderasi Corporate Governance dan Hipotesis Penelitian}

\subsubsection{Multiple Large Shareholders (MLS)}

Large shareholder merupakan pemegang saham yang memiliki proporsi kepemilikan sebesar $5 \%$ dari total saham beredar (Ouyang et al, 2020). Keberadaan large shareholders dapat memberikan dampak bagi perusahaan apabila kepemilikan saham dari pemegang saham utama kurang dari 50\% (Ouyang et al, 2020). Oleh karena itu, pengertian MLS dalam penelitian ini adalah ketika terdapat lebih dari satu pemegang saham dengan kepemilikan diatas $5 \%$ pada perusahaan yang tidak memiliki pemegang saham dengan proporsi kepemilikan diatas $50 \%$.

MLS dapat memperbaiki masalah keagenan dengan menjadi tambahan pengawas bagi pemegang saham utama maupun manajemen (Ouyang et al, 2020). MLS dapat meningkatkan efektivitas dari corporate governance dalam perannya untuk memitigasi adanya asimetri informasi antara pemilik utama dan minoritas (Attig et al, 2008). MLS dapat mempengaruhi corporate governance melalui dua cara (Chen et al, 2019), yaitu melalui intervensi langsung dengan hak suara mereka (Jiang et al, 2018; Baroso et al, 2016; Edmans, 2014) ataupun melalui penjualan saham mereka dalam artian keluar dari perusahaan (Cheng et al, 2017; Edmans dan Manso; 2011; Hope et al, 2017). Hal ini membuat keberadaan MLS dapat mempersulit pemegang saham utama untuk memperoleh keuntungan pribadi dan mengorbankan pemegang saham lainnya (Cheng et al, 2013), salah satunya melalui praktek tax avoidance.

MLS dapat memperburuk masalah keagenan dengan bekerja sama dengan pemegang saham utama dan mengorbankan pemegang saham minoritas (Ouyang et al, 2020). MLS dan pemegang saham utama akan bertindak sesuai keuntungan dan kepentingan mereka, seperti melakukan transaksi antar pihak yang saling terkait demi keuntungan pribadi mereka. Hal ini dapat memicu adanya perilaku penghematan pajak melalui tax avoidance (Slemrod, 2004 dalam Ouyang et al, 2020).

Dengan teori ini, hipotesis yang dibuat adalah:

H4: MLS memperlemah pengaruh positif dari setiap struktur kepemilikan terhadap perilaku tax avoidance.

\subsubsection{Proporsi Komisaris Independen}

Keberadaan komisaris yang independen dapat menjadi "professional referee" dalam rangka meningkatkan kompetisi antar direktur manajerial untuk memenuhi kepentingan pemegang saham (Fama, 1980). Keberadaan dari komisaris independen dapat meningkatkan efektifitas dari pengawasan manajemen dan meningkatkan kepatuhan perusahaan (Lanis dan Richardson, 2011), serta dapat berperan sebagai mediator ketika terjadi ketidaksepakatan antar manajer dalam keputusan yang dapat melibatkan masalah keagenan (Fama dan Jansen, 1983).

Di Indonesia sendiri keberadaan komisaris independen diatur dalam peraturan otoritas jasa keuangan (POJK) nomor 33 tahun 2014. Keberadaan komisaris independen sifatnya wajib bagi semua perusahaan terbuka dengan proporsi paling kecil 30\% dari total seluruh komisaris. Pada kenyataannya, aturan tersebut tidak sepenuhnya dipatuhi oleh perusahaan publik di Indonesia. Darwis (2009) mengungkapkan bahwa keberadaan komisaris independen di perusahaan hanya untuk memenuhi syarat dari peraturan tersebut. Komisaris independen tidak melaksanakan fungsi pengawasan dengan tepat dan tidak menggunakan independensinya untuk mengamati kebijakan dari direksi (Septiya dan Novita, 2018). Hal ini dikarenakan besarnya kewenangan dan peran dari pemegang saham utama (Hardiningsih, 2010).

Atas variabel proporsi komisaris independen, maka dibuat hipotesis sebagai berikut: 
H5: Komisaris independen memperlemah pengaruh positif dari setiap struktur kepemilikan terhadap perilaku tax avoidance.

\subsubsection{Kualitas Audit}

Kualitas audit dapat mengurangi konflik kepentingan antara manajer dan pemegang saham perusahaan (Gaaya et al, 2017). Kualitas audit dari perusahaan salah satunya ditentukan oleh kualitas auditor eksternal perusahaan. Auditor eksternal dapat berperan sebagai pihak independen yang menilai laporan keuangan perusahaan (Gaaya et al, 2017). Auditor eksternal juga dapat menilai apakah klien mereka melakukan tindakan tax avoidance yang dapat berujung pemeriksaan oleh otoritas pajak (Guenther et al, 2017).

Banyak literatur yang menyebutkan bahwa kualitas audit dari auditor KAP Big4 lebih baik daripada non-Big 4 (Gontara dan Khlif, 2020). Auditor yang memiliki kualitas yang bagus cenderung untuk enggan terlibat dalam praktik tax avoidance (Gaaya et al, 2017). Hal itu disebabkan karena banyak resiko yang akan mereka hadapi apabila terlibat dalam praktik tax avoidance. Konsekuensi terbesar adalah terkait masalah reputasi dari auditor dan adanya biaya litigasi di masa depan (Gaaya et al, 2017). Mereka akan kehilangan reputasi dan kepercayaan dari publik apabila praktik penghindaran pajaknya terungkap oleh otoritas pajak (Hanlon dan Slemrod, 2009).

Peraturan mengenai akuntan publik di Indonesia dituangkan dalam Undang- Undang (UU) nomor 5 tahun 2011 dan Peraturan OJK (POJK) nomor 13 tahun 2017. Dalam UU nomor 5 tahun 2011 disebutkan bahwa kantor akuntan publik dapat memberikan beberapa jasa kepada kliennya, antara lain jasa audit, jasa reviu, jasa asurans lainnya, dan jasa lainnya yang berkaitan dengan akuntansi, perpajakan, keuangan, dan manajemen. Pemberian jasa perpajakan oleh KAP dapat menimbulkan kemungkinan bahwa KAP Big 4 dapat membantu kliennya untuk mengecilkan pembayaran pajaknya secara legal (Septiya dan Novita, 2018).

Atas variabel ini, hipotesis yang dibuat adalah:

H6: Auditor dari KAP Big 4 memperlemah pengaruh positif dari setiap struktur kepemilikan terhadap perilaku tax avoidance.

\subsection{Perumusan Masalah Hipotesis}

Dalam rangka memudahkan pemahaman, peneliti menyusun hubungan antar variabel dalam sebuah perumusan masalah seperti yang digambarkan sebagai berikut.

Gambar 1. Perumusan Masalah

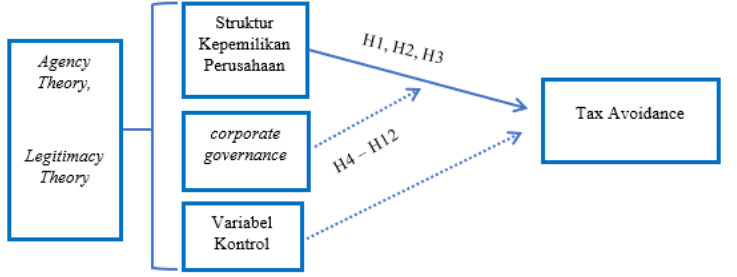

\section{METODE PENELITIAN}

\subsection{Objek Penelitian Dan Teknik Pemilihan Sampel}

Data yang digunakan dalam penelitian ini merupakan data sekunder yang diperoleh dari laporan keuangan, laporan tahunan perusahaan, ataupun media informasi lainnya. Data yang diolah merupakan data panel, yaitu sebuah data cross sectional unit yang akan di observasi dalam berbagai waktu yang berbeda. Penelitian ini menggunakan aplikasi STATA16 dalam pengolahan datanya.

Populasi dari penelitian ini adalah perusahaan yang terdaftar di bursa efek Indonesia periode 20172019. Dari populasi penelitian tersebut kemudian dilakukan pengambilan sampel, yang merupakan bagian dari populasi (Sekaran, 2017). Teknik pengambilan sampel yang digunakan dalam penelitian ini adalah teknik non-probability sampling dengan menggunakan purposive sampling. Purposive sampling merupakan teknik untuk menentukan sampel penelitian dengan beberapa pertimbangan tertentu dengan tujuan agar data yang diperoleh nantinya bisa lebih representatif (Sugiyono, 2014).

Penulis menentukan beberapa kriteria bagi data yang akan diambil untuk penelitian diantaranya a) Perusahaan yang tidak masuk dalam sektor keuangan maupun property dan real estate, b) Perusahaan yang telah melakukan initial public offering (IPO) sebelum 1 Januari 2017, c) Perusahaan yang tidak mengalami kerugian pada periode 2017-2019, d) Perusahaan yang menggunakan nilai rupiah dalam pelaporan keuangannya, e) Perusahaan yang memiliki data dan laporan lengkap selama periode 2017-2019.

\subsection{Model Penelitian Dan Pengukuran Variabel}

Dalam rangka melakukan pengujian hubungan antara struktur kepemilikan perusahaan dengan tax avoidance, model regresi yang digunakan adalah sebagai berikut.

TAi,t $=\alpha 1+\beta 1 F A M I L Y i, t+\beta 2 F O R E I G N i, t+$ B3GOVERNMENTi,t $+\beta 4$ SIZEi,t $+\beta$ PPROFITi,t + $\beta 6$ LEVERAGEi, $t+\beta 7 P P E i, t+\varepsilon$

Variabel TA (tax avoidance) dihitung dengan menggunakan dua jenis pengukuran, yaitu rasio ETR dan BTD. ETR (Efective Tax Ratio) dihitung dengan melakukan pembagian antara beban pajak kini dengan laba sebelum pajak (Armstrong et al, 2012; Chen et al, 2010; Dyreng et al, 2010; Huseynov dan Klamm, 2012; Salihu et al, 2015). BTD (Book Tax Different) dihitung 
dengan melakukan pembagian antara selisih laba akuntansi dan laba pajak dengan total aset (Ouyang et al, 2020; Gaaya et al, 2017).

FAMILY merupakan simbol untuk kepemilikan keluarga dalam sebuah perusahaan. Family diukur menggunakan menggunakan angka nilai persentase total dari kepemilikan keluarga dalam suatu perusahaan (Gaaya et al, 2017). FOREIGN merupakan simbol untuk kepemilikan pihak asing dalam sebuah perusahaan. Foreign diukur menggunakan angka nilai persentase total dari kepemilikan pihak asing dalam suatu perusahaan (Hannifa dan Cooke, 2002; Salihu et al, 2015). GOVERNMENT merupakan simbol untuk kepemilikan pemerintah dalam sebuah perusahaan. Government diukur menggunakan angka nilai persentase total dari kepemilikan pemerintah dalam suatu perusahaan (Annuar et al, 2014).

Untuk menguji efek moderasi dari corporate governance, penulis menggunakan model interaksi antara MLS, keberadaan komisaris independen, dan kualitas audit dengan struktur kepemilikan. Penulis menggunakan tiga model berbeda untuk menguji efek moderasi dari masing-masing pengukuran. Model penelitian untuk menguji efek moderasi MLS terhadap struktur kepemilikan (model 2A) digambarkan sebagai berikut.

Tai,t $=\alpha 1+\beta 1 F A M I L Y i, t+\beta 2 F O R E I G N i, t+$ $\beta 3$ GOVERNMENTi,t $+\beta 4 M L S i, t+\beta 5 F A M I L Y i, t X M L S i, t+$ $\beta 6 F O R E I G N i, t \times M L S i, t+\beta 7 G O V E R N M E N T i, t \times M L S i, t+$ $\beta 8$ SIZEi, $t+\beta$ 9PROFITi, $t+\beta 10$ LEVERAGEi, $t+\beta 11$ PPEi, $t+$ $\varepsilon$

MLS merupakan sebuah kondisi jika dalam suatu perusahaan yang tidak memiliki pemegang saham dengan kepemilikan diatas $50 \%$ dan terdapat lebih dari satu pemegang saham besar. MLS diukur menggunakan dummy variabel dengan memberi angka 0 untuk perusahaan yang tidak memiliki MLS dan angka 1 untuk perusahaan yang memiliki MLS (Ouyang et al, 2020).

Model penelitian untuk menguji efek moderasi keberadaan komisaris indepeden terhadap struktur kepemilikan (model 2B) adalah sebagai berikut.

Tai,t $=\alpha 1+\beta 1 F A M I L Y i, t+\beta 2 F O R E I G N i, t+$ $\beta 3 G O V E R N M E N T i, t+\beta 4 K O M I N D i, t+\beta 5 F A M I L Y i, t \quad X$ KOMINDi,t $+\beta 6 F O R E I G N i, t \quad X$ KOMINDi,t + $\beta$ 7GOVERNMENTi,t $\times$ KOMINDi,t $+\beta 8$ SIZEi,t + $\beta$ PPROFITi, $t+\beta 1$ LLEVERAGEi, $t+\beta 11$ PPEi, $t+\varepsilon$

KOMIND merupakan simbol untuk keberadaan komisaris independen dalam dewan komisaris perusahaan. KOMIND diukur menggunakan persentase keberadaan komisaris independen dibandingkan dengan total komisaris yang ada dalam sebuah perusahaan (Annuar et al, 2014; McClure et al; 2018, Lanis dan Richadson, 2011).

Model penelitian untuk menguji efek moderasi kualitas audit terhadap struktur kepemilikan (model 2C) adalah sebagai berikut.

Tai,t $=\alpha 1+\beta 1 F A M I L Y i, t+\beta 2 F O R E I G N i, t+$ $\beta 3 G O V E R N M E N T i, t+\beta 4 B I G 4 i, t+\beta 5 F A M I L Y i, t$ X BIG4i,t $+\beta 6 F O R E I G N i, t X$ BIG4i,t $+\beta 7 G O V E R N M E N T i, t X$ BIG4i,t $+\beta 8$ SIZEi, $t+\beta$ 9PROFITi, $t+\beta 10$ LEVERAGEi, $t+\beta 11$ PPEi, $t$ $+\varepsilon$

BIG4 merupakan sebuah kondisi jika perusahaan menggunakan jasa kantor akuntan publik (KAP) terafiliasi Big 4 sebagai auditor eksternalnya. BIG4 diukur menggunakan dummy variabel dengan memberi angka 0 untuk perusahaan yang tidak menggunakan jasa KAP Big 4 dan angka 1 untuk perusahaan yang menggunakan jasa KAP Big 4 (Gaaya et al, 2017).

Penelitian ini menggunakan empat variabel kontrol, yaitu SIZE, PROFIT, LEVERAGE, dan PPE. SIZE (ukuran perusahaan) digunakan untuk menangkap dan memitigasi variasi dari level investasi perusahaan dalam aset hubungannya dengan insentif pajak (Salihu et al, 2015). SIZE diukur dengan menggunakan logaritma natural dari nilai total aset yang dimiliki suatu perusahaan (Hannifa dan Cooke, 2002; Gaaya et al, 2017; Salihu et al, 2015). PROFIT (profitabilitas) dimasukan sebagai variabel kontrol untuk mendokumentasikan tingginya ETR pada perusahaan yang memiliki laba yang tinggi (Salihu et al, 2015). Nilai PROFIT diukur dengan menggunakan ROA yaitu persentase dari laba bersih dibagi dengan total aset (Gaaya et al, 2017). LEVERAGE (solvabilitas) digunakan untuk melihat efek utang karena beban bunga merupakan biaya yang dapat mengurangi pembayaran pajak (Salihu et al, 2015). Variabel LEVERAGE diukur dengan melakukan pembagian antara total kewajiban dengan total aset (Chen et al, 2010; Gayaa et al, 2017). PPE (fix asset ratio) digunakan untuk melihat efek dari adanya beban depresiasi terhadap pajak dan pelaporan keuangan (Chen et al, 2010). Variabel ini diukur dengan menggunakan pembagian antara total property, plant, and equipment dengan total aset dari perusahaan (Chen et al, 2010; Salihu et al, 2015).

\section{HASIL PENELITIAN}

\subsection{Statistik Deskriptif}

Jumlah perusahaan yang menjadi sampel dalam penelitian ini adalah sebanyak 141 perusahaan. Jika dibagi berdasarkan struktur kepemilikannya adalah 103 perusahaan perusahaan dengan kepemilikan keluarga (73\%), 27 perusahaan dengan kepemilikan asing (19\%), dan 11 perusahaan dengan kepemilikan pemerintah (8\%). Jumlah perusahaan yang memiliki MLS adalah sebanyak 18 perusahaan pada tahun 2017 dan 2018 (12.7\%) dan 19 perusahaan pada tahun 2019 (13.48\%). Sedangkan jumlah perusahaan yang menggunakan jasa KAP terafiliasi BIG 4 adalah sebanyak 62 perusahaan pada tahun 2017 (43,97\%), 61 perusahaan pada tahun 2018 (43,26\%), dan 60 perusahaan pada tahun 2019 $(42,55 \%)$. Adapun statistik deskriptif dalam penelitian ini ditunjukan dalam Tabel I. Statistik Deskriptif. 


\subsection{Pengujian yang Dilakukan}

\subsubsection{Pemilihan Metode Regresi Data Panel}

Metode atau model regresi data panel dibagi menjadi tiga jenis yaitu common effect model atau pooled least square, fixed effect model, dan random effect model. Pemilihan model regresi yang tepat harus disesuaikan dengan data penelitian. Terdapat tiga jenis pengujian dalam proses pemilihan model regresi yang tepat antara lain uji chow, uji breusch-pagan langrange multiplier, dan uji hausman. Hasil pemilihan metode regresi pada penelitian ini ditunjukan oleh tabel 2 . Pemilihan Metode Regresi Data Panel.

\subsubsection{Uji Aumsi Klasik}

Uji asumsi klasik dilakukan agar model regresi dapat memenuhi asumsi BLUE (best linier unbiased estimate) dan terhindar dari masalah bias (Gujarati, 2004). Secara umum, uji asumsi klasik yang dapat dilakukan antara lain uji normalitas, uji multikolinearitas, uji heteroskedastisitas, dan uji autokorelasi. Pemilihan uji asumsi klasik juga didasarkan pada model atau metode penelitian yang terpilih. Penelitian dengan model fixed effect memerlukan keempat pengujian asumsi klasik tersebut agar dapat terbebas dari bias. Penelitan dengan model random effect tidak memerlukan uji heteroskedastisitas dan uji autokorelasi. Hal ini dikarenakan penggunaan asumsi Generalized Least Square (GLS) pada model random effect sudah memfasilitasi masalah heteroskedastisitas dan autokorelasi (Gujarati, 2004).

Penelitian ini memiliki jumlah observasi sebanyak 423 observasi $(>100)$. Jumlah pengamatan yang besar tidak perlu mempermasalahkan asumsi normalitas (central limit theorema, Gujarati, 2004). Oleh karena itu, penelitian ini telah memenuhi asumsi normalitas.

Uji multikolinearitas dilakukan dengan menggunakan uji variance inflation factors (VIF). Nilai VIF dari seluruh variabel independen dan kontrol pada model 1 memiliki nilai dibawah 10. Hal ini menunjukan bahwa tidak ada masalah multikolinearitas pada model 1. Pada model $2 \mathrm{~A}, 2 \mathrm{~B}$, dan $2 \mathrm{C}$ terdapat nilai vif lebih dari 10 pada variabel yang karena adanya efek moderasi. Masalah multikolinearitas yang tercipta karena pembentukan keberadaan pengaruh moderasi tidak bersifat problematik (Sugiyono, 2014). Multikolinearitas tersebut timbul karena adanya penskalaan interval antar variabel bebas dan tidak menimbulkan masalah multikolinearitas yang serius (Disatnik dan Sivan, 2016).

Seluruh model penelitian yang menggunakan metode fixed effect mengalami masalah heteroskedastisitas. Hal ini ditunjukan dengan nilai prob>chi2 sebesar 0.0000 yang lebih kecil dari nilai signifikansi (0.5). Masalah heteroskedastisitas pada model penelitian dengan metode fixed effect harus diatasi supaya dapat menghasilkan hasil regresi yang sesuai dengan kaidah BLUE. Masalah heteroskedastisitas dapat diatasi dengan menggunakan robust Driscoll-Kraay (Hoechle, 2007).

Semua model penelitian yang menggunakan metode fixed effect mengalami masalah autokorelasi. $\mathrm{Hal}$ ini ditunjukan dengan nilai prob $>\mathrm{F}$ yang lebih kecil daripada nilai signifikansi $(0,5)$. Masalah autokorelasi pada model penelitian dengan metode fixed effect harus diatasi supaya dapat menghasilkan hasil regresi yang sesuai dengan kaidah BLUE. Sama seperti masalah heteroskedastisitas, masalah autokorelasi dapat diatasi dengan menggunakan robust Driscoll-Kraay (Hoechle, 2007).

\subsection{Pembahasan Hasil Penelitian}

\subsubsection{Pengaruh Kepemilikan Keluarga Terhadap Tax Avoidance}

Hasil pengujian pada penelitian ini menunjukan bahwa kepemilikan keluarga dalam perusahaan berpengaruh positif terhadap perilaku tax avoidance. Hasil penelitian ini selaras dengan hasil penelitian sebelumnya dari Gaaya et al (2017) dan Kovermann dan Wendt (2019) dan berbeda dengan yang diungkapkan oleh Chen et al (2010) dan Rusydi dan Martani (2014). Hasil dari penelitian ini seragam untuk kedua jenis pengukuran tax avoidance, yaitu ETR dan BTD. Pengujian menggunakan perhitungan ETR dan BTD menunjukan bahwa perusahaan dengan kepemilikan keluarga berpengaruh positif terhadap tindakan tax avoidance. Rata-rata proporsi kepemilikan keluarga dalam perusahaan adalah sebesar 62,93 persen. Hal ini menunjukan bahwa pihak keluarga sebagai pemegang saham utama dari perusahaan memiliki kontrol yang besar atas perusahaan. Kondisi ini membuat peluang bagi perusahaan untuk melakukan praktik rent extraction melalui tax avoidance semakin besar (Gaaya et al, 2017).

Hasil penelitian ini mendukung expropriation hypothesis yang terkait dengan teori agensi yang diungkapkan oleh Jensen dan Meckling (1976). Hal ini menunjukan bahwa pihak keluarga sebagai pemegang saham utama memilih untuk mengambil lebih banyak keuntungan dari adanya penghematan pajak dan dapat mengorbankan kepentingan pemegang saham minoritas (Gaaya et al, 2017). Tindakan tax avoidance dapat digunakan pihak keluarga untuk menutupi kerugian, menutupi tindakan rent extraction, dan pada akhirnya untuk mengelabui pemegang saham minoritas (Desai dan Dharmapala, 2006). Sebaliknya, hasil penelitian ini tidak mendukung hipotesis "kontrak sosial" dari teori legitimasi. Pengaruh positif dari hubungan antara kepemilikan keluarga dengan tax avoidance bertentangan dengan harapan masyarakat terhadap perusahaan. Keterlibatan perusahaan dalam perilaku tax avoidance dapat dipandang sebagai tindakan yang tidak etis (Landolf dan Symons, 2008) dan dapat menimbulkan kerugian bagi masyarakat (Lanis dan Richardson, 2013). 
Kovermann dan Wendt (2019) menyatakan bahwa salah satu cara yang seringkali digunakan perusahaan dengan kepemilikan keluarga dalam tax avoidance adalah melalui transaksi pihak dengan hubungan istimewa. Peningkatan pengawasan dan pemeriksaan terkait dengan transaksi dengan pihak yang memiliki hubungan istimewa dapat menjadi salah satu cara yang dapat digunakan Direktorat Jenderal Pajak untuk mengatasi masalah ini. Hasil penelitian ini didukung oleh sejumlah fakta yang terjadi di Indonesia yang menunjukan keterlibatan perusahaan dengan kepemilikan keluarga dalam tindakan tax avoidance. Kasus tersebut diantaranya adalah kasus PT Asian Agri yang dimiliki oleh keluarga Tanoto, kasus Kaltim Prima Coal dan kasus Bumi Resources, perusahaan yang dimiliki keluarga Bakrie.

\subsubsection{Pengaruh Kepemilikan Asing Terhadap Tax Avoidance}

Hasil pengujian pada penelitian ini menunjukan bahwa kepemilikan asing dalam perusahaan berpengaruh positif terhadap perilaku tax avoidance. Hasil ini sejalan dengan hasil penelitian sebelumnya dari Kiney dan Lawrence (2000), dan Salihu et al (2015). Hal ini menunjukan bahwa masih adanya potensi terdapat masalah keagenan pada perusahaan dengan kepemilikan asing. Terdapat indikasi bahwa pihak asing selaku pemegang saham utama perusahaan memilih memanfaatkan penghematan pajak dan mengorbankan pemegang saham minoritas sesuai expropriation hypothesis yang diungkapkan Jensen dan Meckling (1976). Hasil ini selaras dengan pernyataan Salihu et al (2015) bahwa perusahaan dengan kepemilikan asing lebih memilih manfaat dari adanya perilaku tax avoidance dibandingkan dengan resikonya. Salihu et al (2015) menambahkan bahwa perusahaan dengan kepemilikan asing lebih mementingkan keuntungan dari tax avoidance dibandingkan dengan isu legitimasi. Hasil ini juga sesuai dengan yang diungkapkan oleh mantan Direktur P2 Humas DJP, Mekar Satria Utama pada tahun 2016 lalu. Mekar Satria Utama (2016) mengungkapkan bahwa terdapat sekitar 2000 perusahaan Penanaman Modal Asing (PMA) yang tidak membayar pajak dengan alasan merugi. Beliau menambahkan bahwa seharusnya perusahaan tersebut membayar rata-rata Rp25 miliar per tahun (dikutip dari liputan6.com, 25 Januari 2021).

Salah satu mekanisme yang digunakan oleh perusahaan dengan kepemilikan asing dalam tindakan tax avoidance-nya adalah profit shifting melalui kegiatan transfer pricing (Shan, 2013). Hal ini senada dengan yang diungkapkan oleh Mekar Satria Utama bahwa skema yang digunakan perusahaan asing untuk menghindari pajak adalah melalui transfer pricing. Pengawasan dan penegakan hukum yang lebih ketat dapat menjadi senjata bagi Direktorat Jenderal Pajak untuk memerangi perilaku transfer pricing. Insentif perusahaan untuk melakukan praktik transfer pricing akan lebih kecil di negara yang memiliki aturan dan penegakan hukum yang ketat (Bartelsman dan Beetsma, 2003).

\subsubsection{Pengaruh Kepemilikan Pemerintah Terhadap Tax Avoidance}

Hasil pengujian pada penelitian ini menunjukan bahwa kepemilikan pemerintah dalam perusahaan berpengaruh positif terhadap perilaku tax avoidance. Hasil ini sejalan dengan hasil penelitian sebelumnya dari Tang (2016) dan berbeda dengan yang diungkapkan oleh Bradshaw et al (2019).

Perusahaan dengan kepemilikan pemerintah di Indonesia (BUMN/ BUMD) sudah melakukan kerjasama dengan Direktorat Jenderal Pajak dalam rangka meningkatkan kepatuhan perpajakan. Kerjasama itu berbentuk integrasi data antara BUMN dengan Direktorat Jenderal Pajak. Namun, adanya kerjasama ini belum menjamin bahwa perusahaan dengan kepemilikan pemerintah bebas dari tax avoidance. Fenomena terkini terkait perilaku tax avoidance pada perusahaan BUMN yang mendukung hasil penelitian ini terjadi pada kasus sengketa pajak Perusahaan Gas Negara (PGN). Hal ini dapat menjadi masukan bagi Direktorat Jenderal Pajak untuk tidak melonggarkan pengawasan terhadap BUMN meskipun sudah ada kerjasama antara keduanya. Pengawasan yang dilakukan Direktorat Jenderal Pajak dapat meminimalisir adanya kesalahan teknis perpajakan, perbedaan penafsiran aturan seperti pada kasus PGN, maupun kegiatan lainnya yang dapat mengurangi nilai pajak yang seharusnya dibayar.

Keberadaan koneksi politik dalam perusahaan dengan kepemilikan pemerintah dapat menjadi salah satu perhatian. Koneksi politik dapat dilihat dari keberadaan pejabat pemerintah maupun politikus yang menduduki kursi kepemimpinan di BUMN/ BUMD (Ilmi et al, 2017). BUMN yang memiliki koneksi politik dalam susunan pimpinannya memiliki kecenderungan untuk melakukan tindakan tax avoidance (IImi et al, 2017). Hasil penelitian ini mendukung pernyataan dari Ilmi et al (2017). Perusahaan dengan kepemilikan pemerintah dalam penelitian ini seluruhnya memiliki koneksi politik dalam struktur kepemimpinannya.

Hasil penelitian ini juga menunjukan masih adanya indikasi dari masalah keagenan dalam perusahaan dengan kepemilikan pemerintah. Chen et al (2008) dan Fan et al (2007) menyatakan bahwa perusahaan dengan kepemilikan pemerintah memiliki tingkat keuntungan dan efisiensi yang rendah, tata kelola yang buruk, serta konflik keagenan yang lebih parah antara pemilik mayoritas dengan minoritas (principle-to-principle). Berbagai permasalahan ini tercermin dalam beberapa kasus yang menjerat BUMN diantaranya berupa kasus rekayasa laporan keuangan yang dilakukan PT Garuda Indonesia, kasus PT Jiwasraya, hingga kasus korupsi pada beberapa BUMN (PT PLN, PT Pertamina, PT Krakatau Steel). 
4.3.4. Pengaruh Moderasi MLS Terhadap Pengaruh Struktur Kepemilikan (Keluarga Dan Asing) Terhadap Tax Avoidance

Hasil pengujian dalam penelitian ini menunjukan bahwa keberadaan MLS memperlemah pengaruh kepemilikan keluarga terhadap tax avoidance. Hasil ini memperkuat hasil penelitian sebelumnya dari Ouyang et al (2020). Ouyang et al (2020) menyebutkan bahwa keberadaan dari MLS dapat menjadi tambahan pengawas bagi perusahaan. Keberadaan MLS dalam perusahaan dengan kepemilikan keluarga dan asing dapat menurunkan kemungkinan tindakan tax avoidance. Pengaruh dari kepemilikan keluarga dan asing terhadap tax avoidance berubah dari pengaruh positif menjadi pengaruh negatif dengan keberadaan MLS. Keberadaan MLS dapat mempersulit direksi dan pemegang saham utama untuk melakukan pencurian kekayaan perusahaan melalui tindakan tax avoidance. MLS dapat mengurangi masalah keagenan antara pemegang saham utama dan pemegang saham minoritas. MLS dapat meningkatkan efektivitas dari corporate governance. Keberadaan MLS dapat membuat perusahaan untuk bertindak sesuai dengan kepentingan dan legitimasi sosial.

\subsubsection{Pengaruh Moderasi Keberadaan Komisaris} Independen Terhadap Pengaruh Struktur Kepemilikan (Keluarga, Asing, Dan Pemerintah) Terhadap Tax Avoidance

Hasil pengujian dalam penelitian ini menunjukan bahwa keberadaan komisaris independen tidak memoderasi pengaruh dari adanya struktur kepemilikan terhadap tax avoidance. Hasil dalam penelitian serupa dengan hasil dari penelitian sebelumnya dari Septiya dan Novita (2018) dan berbeda dengan penelitian yang dilakukan oleh Lanis dan Richardson (2011), dan McClure et al (2018). Darwis (2009) menyatakan bahwa peran dari komisaris independen untuk mengawasi perusahaan tidak berjalan dengan baik. Darwis (2009) menambahkan bahwa penyebab dari hal tersebut adalah keberadaan dari komisaris independen dalam perusahaan hanya untuk memenuhi regulasi dari Otoritas Jasa Keuangan (OJK). OJK mensyaratkan bahwa setiap perusahaan terbuka paling kecil memiliki proporsi komisaris Independen sebanyak $30 \%$. Hal ini juga menyebabkan menyebutkan bahwa komisaris independen pada faktanya tidak memiliki independensi (Hardiningsih, 2010). Pengawasan yang dilakukan oleh komisaris independen menjadi tidak efektif akibat dari besarnya kendali yang dipegang pemegang saham utama (Hardiningsih, 2010). Hal ini membuat pengaruh dari komisaris independen terhadap tax avoidance jadi bias. Pengaruh dari komisaris independen bergantung pada pihak lain berupa besarnya kekuatan pengendalian dari pemegang saham utama.

\subsubsection{Pengaruh Moderasi Keberadaan Auditor Dari} KAP Big 4 Terhadap Pengaruh Struktur
Kepemilikan (Keluarga, Asing, Dan Pemerintah) Terhadap Tax Avoidance

Hasil dari pengujian dalam penelitian ini menunjukan bahwa moderasi dari adanya auditor dari KAP Big4 memperkuat pengaruh struktur kepemilikan terhadap tax avoidance. Hasil dalam penelitian ini berbeda dengan yang diungkapkan oleh Gaaya et al (2017) dan Septiya dan Novita (2018) dalam penelitiannya. Septiya dan Novita (2018) menyatakan bahwa terdapat kemungkinan bagi kantor akuntan publik Big 4 untuk memberikan layanan konsultasi terkait perpajakan kepada perusahaan. Hal ini yang disinyalir dapat membuat peran pengawasan dari KAP Big4 menjadi berkurang. KAP Big 4 dapat membantu perusahaan untuk mencari cara legal dalam mengecilkan pembayaran pajaknya (Septiya dan Novita, 2018). Praktik dari tax avoidance masih bisa terjadi dengan adanya bantuan konsultasi perpajakan dari KAP Big4. Direktorat Jenderal Pajak perlu tetap mengawasi perusahaan meskipun mereka sudah diaudit oleh KAP besar (Big 4). Hasil penelitian ini didukung oleh beberapa fenomena yang terjadi di Indonesia. Perusahaan Gas Negara (PGN) yang terlibat dalam sengketa pajak pada periode 2012-2017 diaudit oleh KAP terafiliasi Big 4 (PwC dan EY). Adaro Energy yang tersangkut kasus penghindaran pajak melalui pengalihan laba periode 2009-2017 diaudit oleh KAP terafiliasi Big 4 (PwC).

\section{KESIMPULAN}

Tujuan dari penelitian ini adalah untuk mengetahui efek dari kepemilikan keluarga, asing, dan pemerintah terhadap perilaku tax avoidance. Penelitian yang dilakukan terhadap 141 perusahaan yang terdaftar dalam Bursa Efek Indonesia periode 2017-2019 menunjukan bahwa terdapat pengaruh positif dari ketiga struktur kepemilikan tersebut terhadap tax avoidance. Setiap struktur kepemilikan dalam perusahaan tersebut cenderung untuk melakukan tindakan penghematan pajak melalui tax avoidance. Temuan ini cukup menarik dan didukung oleh beberapa fenomena yang terjadi di Indonesia, baik itu pengungkapan tax avoidance oleh otoritas pajak maupun pencapaian target penerimaan pajak yang dibawah target.

Penelitian ini juga mencoba untuk mengetahui efek moderasi dari pengawasan yang dilakukan oleh komisaris independen, MLS, dan auditor eksternal dalam setiap struktur kepemilikan terhadap tax avoidance. Hasil penelitian menunjukan bahwa pengawasan yang dilakukan oleh pemegang saham besar lainnya (MLS) efektif untuk mengurangi kemungkinan perusahaan terlibat dalam tax avoidance. Keberadaan MLS mengubah pengaruh dari struktur kepemilikan keluarga dan asing menjadi negatif terhadap tax avoidance. Hasil sebaliknya diperoleh dari 
pengawasan oleh auditor eksternal (KAP Big 4) yang justru memperkuat pengaruh dari setiap struktur kepemilikan terhadap tax avoidance. Hal ini diduga disebabkan oleh adanya jasa perpajakan yang diberikan KAP Big 4. Sementara untuk pengawasan oleh komisaris independen tidak memoderasi setiap struktur kepemilikan terhadap tax avoidance. Hal ini diduga karena peran yang belum efektif dari keberadaan komisaris independen dalam perusahaan.

Penelitian ini juga menggambarkan hubungan antara teori agensi dan teori legitimasi dengan tax avoidance. Dimana teori agensi dan teori legitimasi mempengaruhi tax avoidance, baik secara positif maupun negatif dibeberapa kondisi.

\section{IMPLIKASI DAN KETERBATASAN}

Penelitian ini diharapkan mampu menambah implikasi atas penelitian struktur kepemilikan perusahaan terhadap tax avoidance dengan ditambah beberapa faktor sebagai moderator. Sehingga penelitian, terutama yang berkaitan dengan tax avoidance, makin mempunyai masukan dengan menggunakan beberapa indikator yang tersedia.

Jurnal ini juga mempunyai beberapa keterbatasan dan saran dalam penulisannya. Keterbatasan dan saran yang ada pada hasil penelitian ini antara lain :

1. penelitian ini menggunakan perusahaan non keuangan yang terdaftar di BEI periode 2017-2019. Hasil penelitian bisa berbeda apabila menggunakan jangka waktu yang berbeda dan sektor yang berbeda. Penelitian ini juga tidak dapat menggeneralisir perilaku seluruh perusahaan di Indonesia.;

2. penelitian selanjutnya dapat menggunakan pengukuran lain dalam tax avoidance, struktur kepemilikan perusahaan (terpusat, manajerial, institusional) maupun corporate governance (pengawasan pemerintah, pasar modal, insentif manajemen);

3. penelitian serupa dapat dilakukan menggunakan metode kualitatif, terutama untuk bisa mendeteksi perilaku tax avoidance yang lebih agresif;

4. bagi investor, hasil penelitian ini diharapkan dapat menjadi pertimbangan untuk memilih perusahaan yang aman untuk investasi;

5. bagi Direktorat Jenderal Pajak, penelitian ini diharapkan dapat menjadi salah satu masukan mengenai adanya potensi penerimaan pajak yang lebih besar yang bisa diperoleh dari perusahaan terbuka non keuangan di Indonesia;

6. Penelitian tentang tax avoidance, dengan meneliti fenomena transfer pricing, mungkin akan dapat memberikan hasil yang lebih baik.

\section{DAFTAR PUSTAKA (REFERENCES)}

Adler, R., Mansi, M. and Pandey, R. 2018. Biodiversity and threatened species reporting by the top Fortune Global companies. Accounting, Auditing and Accountability Journal, Vol. 31 No. 3, pp. 787-825.

Aggarwal, R., Erel, I., Ferreira, M., Matos, P., 2011. Does governance travel around the world? Evidence from institutional investors. J. Financ. Econ. 100 (1), 154-181.

Anderson, H., Chi, J., Liao, J. 2019. Foreign strategic ownership and minority shareholder protection. Emerging Markets Review 39 (2019) 34-49.

Ang, J.S., Cole, R.A., Lin, J.W., 2000. Agency costs and ownership structure. J. Finance 55 (1), 81-106.

Annuar, H.A., Salihu, I.A., and Obid, S.N.S. 2014. Corporate ownership, governance and tax avoidance: An interactive effects. Social and Behavioral Sciences 164, 150-160.

Armstrong, C.S., Blouin, J.L., Larcker, D.F., 2012. The incentives for tax planning. J. Account. Econ. 53 (1-2), 391-411.

Attig, N., Guedhami, O., \& Mishra, D. 2008. Multiple large shareholders, control contests, and implied cost of equity. Journal of Corporate Finance, 14(5), 721-737.

Barroso, C.R., Burkert, M., Dávila, A., Oyon, D., 2016. Shareholder protection: the role of multiple large shareholders. Corp. Gov. 24, 105-129.

Bartelsman, E., \& Beetsma, R. 2003. Why pay more? Corporate tax avoidance through transfer pricing in OECD countries. Journal of Public Economics, 87, 2225-2252.

Bauer, A. M. 2016. Tax avoidance and the implications of weak internal controls. Contemporary Accounting Research, 33, 449-486.

Bennedsen, M., \& Wolfenzon, D. 2000. The balance of power in closely held corporations. Journal of Financial Economics, 58(1-2), 113-139.

Berkman, H., Cole, R. A., and Fu, L. J. 2009. Expropriation through Loan Guarantees to Related Parties: Evidence from China. Journal of Banking and Finance, 33(1): 141-156.

Berkman, H., Cole, R.A., Fu, L., 2010. Political connections and minority-shareholder protection: evidence from securities-market regulation in China. J. Financ. Quant. Anal. 45, 1391-1417.

Bradshaw, M., Liao, G., \& Ma, M. S. 2018. Agency costs and tax planning when the government is a major Shareholder. Journal of Accounting and Economics, 67(2-3), 255-277.

Bursa Efek Indonesia (accessed November 2020). 2020. Laporan keuangan dan tahunan perusahaan terbuka 
https://www.idx.co.id/perusahaan-

tercatat/laporan-keuangan-dan-tahunan/.

Chen, B., She, J., Wang, X., Lai, J., 2008. Empirical Analyses of Chinese non-State-Owned Enterprises (In Chinese). Shenzhen Stock Exchange working paper.

Chen, F., Huyghebaert, N., Lin, S., and Wang, L. 2019. Do multiple large shareholders reduce agency problems in statecontrolled listed firms? Evidence from China. Pacific-Basin Finance Journal 57, 101203.

Chen, S., Chen, X., Cheng, Q., Shevlin, T., 2010. Are family firms more tax aggressive than nonfamily firms? J. Financ. Econ. 95 (1), 41-61.

Cheng, M., Lin, B., \& Wei, M. 2013. How does the relationship between multiple large shareholders affect corporate valuations? Evidence from China. Journal of Economics and Business, 70,43-70.

Cheng, M., Lin, B., Lu, R., Wei, M., 2017. Non-controlling large shareholders in emerging markets: evidence from China. J. Corp. Finan.

Christensen, J., Murphy, R., 2004. The social irresponsibility of corporate tax avoidance: taking CSR to the bottom line. Development 47, 37-44.

Claessens, S., Djankov, S., \& Lang, L. H. 2000. The separation of ownership and control in East Asian corporations. Journal of Financial Economics, 58(1-2), 81-112.

Claessens, S., Djankov, S., Fan, J., and Lang, L. 2002. Disentangling the incentive and entrenchment effects of large shareholdings. Journal of Finance 57, 2741-2771.

CNBC Indonesia (accessed 2021, January 25). January 2021. Erick Turun Tangan, Begini Kronologi Kasus Pajak PGN Rp 6,8 T. Diambil kembali dari cnbcindonesia.com: $\quad$ https www.cnbcindonesia.com /market/20210105094526-17-213520/erickturun-tangan-begini-kronologi-kasus-pajakpgn-rp-68-t

D’souza, J., Megginson, W. \& Nash, R. 2001. Determinants of performance, improvements in privatized firms: the role of restructuring and corporate governance, working paper, available on www.ssrn.com.

Dahiya, S.B., Gupta, D., 2004. Foreign investment and issues of corporate governance in India. Working paper, University of Canberra.

Darwis, H. 2009. Corporate Governance Terhadap Kinerja Perusahaan. Jurnal Keuangan dan Perbankan, 13(3), 418-430.

Deegan, C., 2002. Introduction: the legitimatising effect of social and environmental disclosures - a theoretical foundation. Accounting, Auditing and Accountability 15 (3), 282-311.
Deegan, M.C. 2018. Legitimacy theory: Despite its enduring popularity and contribution, time is right for a necessary makeover. Accounting, Auditing \& Accountability Journal. Vol. 32 No. 8, 2019 pp. 2307-2329.

Desai, M.A., Dharmapala, D., 2006. Corporate tax avoidance and high-powered incentives. J. Financ. Econ. 79 (1), 145-179.

Disatnik, D., and Sivan, L. 2016. The multicollinearity illusion in moderated regression analysis. Marketing Letters, Vol. 27, No. 2 (June 2016), pp. 403-408.

Dyreng, S.D., Hanlon, M., Maydew, E.L., 2010. The effects of executives on corporate tax avoidance. Account. Rev. 85 (4), 1163-1189.

Edmans, A., Manso, G., 2011. Governance through trading and intervention: a theory of multiple blockholders. Rev. Financ. Stud. 24, 23952428.

Egger, P., Eggert, W., Winner, H., 2010. Saving taxes through foreign plant ownership. J. Int. Econ. 81, 99-108.

Faccio, M., \& Lang, L. H. 2002. The ultimate ownership of Western European corporations. Journal of Financial Economics, 65(3), 365-395.

Fama, E. F., \& Jensen, M. C. 1983. Separation of ownership and control. Journal of Law and Economics, 26, 301-325.

Fama, E.F., 1980. Agency problems and the theory of the firm. J. Polit. Econ. 88 (2), 288-307.

Fan, J. P. H., Wong, T. J., \& Zhang, T. Y. 2007. Politicallyconnected CEOs, corporate governance and post-IPO performance of China's newly partially privatized firms. Journal of Financial Economics, 84(2), 330-357.

Gaaya, S., Lakhal, N., Lakhal, F., 2017. Does family ownership reduce corporate tax avoidance? The moderating effect of audit quality. Manag. Audit. J. 32, 731-744

Goergen, M., \& Renneboog, L. 2006. Corporate governance and shareholder value. In D. Lowe, \& R. Leiringer (Eds.), Commercial management of projects: Defining the discipline (pp. 100131). Oxford: Blackwell Publishing.

Gontara, H., and Khlif, H., 2020. Tax avoidance and audit report lag in South Africa: the moderating effect of auditor type. Journal of Financial Crime.

Guenther, D., Matsunaga, R. and Williams, M. 2017. Is tax avoidance related to firm risk?. The Accounting Review, Vol. 92 No. 1, pp. 115-136.

Guenther, D.A., Matsunaga, S.R., Williams, B.M., 2017. Is tax avoidance related to firm risk? Account. Rev. 92, 115-136.

Gujarati, D. N. (2004). Basic econometrics (4th ed.). New York: The McGraw-Hill Companies. 
Haniffa, R.M., Cooke, T.E., 2002. Culture, corporate governance and disclosure in Malaysian corporations. Abacus 38 (3), 317-349.

Hanlon, M., Heitzman, S., 2010. A review of tax research. J. Account. Econ. 5 (2-3), 127-178.

Hanlon, M., Slemrod, J., 2009. What does tax aggressiveness signal? Evidence from stock price reactions to news about tax aggressiveness. Journal of Public Economics 93, 126-141.

Hardiningsih, P. 2010. Pengaruh Independensi, Corporate Governance, dan Kualitas Audit Terhadap Integritas Laporan Keuangan. Jurnal Ilmiah Kajian Akuntansi, 2(1).

Heflin, F., \& Shaw, K. W. 2000. Blockholder ownership and market liquidity. Journal of Financial and Quantitative Analysis, 35(4),621-633.

Hoechle, D. 2007. Robust Standard Errors for Panel Regressions with Cross-Sectional Dependence. The Stata Journal 7, Number 3, pp. 281-312.

Hope, O.K., Wu, H., Zhao, W., 2017. Blockholder exit threats in the presence of private benefits of control. Rev. Acc. Stud. 22, 873-902.

Huaili, Lv. 2015. Collusions In Chinese Family Firms: An Informal Institution-Based View Of Multiple Large Shareholders. The Journal of Applied Business Research, Vol. 31 No. 4.

Huseynov, F. and Klamm, B. K. 2012. Tax avoidance, tax management and corporate social responsibility. Journal of Corporate Finance, 18(4), 804-827.

Ilmi, C., Sabrina, D., dan Afriyenis, W. 2017. Analisis Tindakan Penghindaran Pajak Pada Perusahaan BUMN yang Terdaftar di Bursa Efek Indonesia Dalam Perspektif Ekonomi Islam. Al Masraf: Jurnal Lembaga Keuangan dan Perbankan, Vol. 2, No. 2.

Jensen, M.C., Meckling, W.H., 1976. Theory of the firm: Managerial behavior, agency costs and ownership structure. J. Financ. Econ. 3 (4), 305-360.

Jiang, F., Cai, W., Wang, X., \& Zhu, B. 2018. Multiple large shareholders and corporate investment: Evidence from China. Journal of Corporate Finance, 50,66-83.

Jiang, G., Lee, C. M., \& Yue, H. 2010. Tunneling through intercorporate loans: The China experience. Journal of Financial Economics, 98(1), 1-20.

Kanagaretnam, K., Lee, J., Lim, C. Y., \& Lobo, G. J. 2016. Relation between auditor quality and tax aggressiveness: Implications of cross-country institutional differences. Auditing: A Journal of Practice \& Theory, 35(4), 105-135.

Khawar, M. 2003. Productivity and foreign direct investment - evidence from Mexico. J. Econ. Stud. 30 (1), 66-76.

Kinney, M., and Lawrence, J. 2000. An analysis of the relative US tax burden of US corporations having substantial foreign ownership. Natl Tax J. 53, 9-22.

Kovermann, J., Velte, P. 2019. The impact of corporate governance on corporate tax avoidance-A literature review. Journal of International Accounting, Auditing and Taxation. 36, 100270.

Kovermann, J., Wendt, M. 2019. Tax avoidance in family firms: Evidence from large private firms. Journal of Contemporary Accounting and Economics. 15, 145-157.

Landolf, U. and Symons, S. 2008. Applying corporate responsibility to tax, International Tax Review, Vol. 31, pp. 6-13.

Landolf, U., 2006. Tax and corporate responsibility. Int. Tax Rev. 29, 6-9.

Lanis, R. and Richardson, G. 2013. Corporate social responsibility and tax aggressiveness: a test of legitimacy theory. Accounting, Auditing \& Accountability Journal, Vol. 26 No. 1, pp. 75100.

Lanis, R., Richardson, G. 2011. The effect of board of director composition on corporate tax aggressiveness. J. Account. Public Policy 30 (1), 50-70.

Liputan6.com. (2021, January 25). March 2016. 2.000 Perusahaan Asing Gelapkan Pajak Selama 10 Tahun. Diambil kembali dari liputan6.com: https://www.liputan6.com/bisnis/read/24690 89/2000-perusahaan-asing-gelapkan-pajakselama-10-tahun.

Lisowsky, P. 2010. Seeking shelter: empirically modeling tax shelters using financial statement information. Account. Rev. 85, 1693-1720.

Maestrini, V., Luzzini, D., Caniato, F., Ronchi, S. 2018. Effects of monitoring and incentives on supplier performance: An agency theory perspective. International Journal of Production Economics 203, 322-332.

Mahaney, R., Lederer, A. 2003. Information systems project management: an agencytheory interpretation. J. Syst. Software 68 (1), 1-9.

McClure, R., Lanis, R., Wells, P., \& Govendir, B. 2018. The impact of dividend imputation on corporate tax avoidance: The case of shareholder value. Journal of Corporate Finance, 48, 492-514

Ouyang, C., Xiong, J., Huang, K. 2020. Do multiple large shareholders affect tax avoidance? Evidence from China. International Review of Economics and Finance 67, 207-224

Peng, M. W., \& Jiang, Y. 2010. Institutions behind family ownership and control in large firms. Journal of Management Studies, 47(2), 253-273.

Richardson, G., Taylor, G., \& Lanis, R. 2013. The impact of board of director oversight characteristics on corporate tax aggressiveness: An empirical analysis. Journal of Accounting and Public Policy, 32, 68-88. 
Rusydi, M K \& Martani, D. 2014, The effect of ownership structure aggressive tax avoidance, Simposium Nasional Akuntansi 17.

Salihu, I. A., Annuar, H. A., \& Obid, S. N. S. 2015. Foreign investors' interests and corporate tax avoidance: Evidence from an emerging economy. Journal of Contemporary Accounting \& Economics, 11, 138-147.

Sekaran, U., \& Bougie, R. 2017. Metode Penelitian untuk Bisnis. John Wiley \& Sons.

Septiya, L., \& Novita, S. 2018. The Impact of Ownership Structure, Independent Commissioners, Audit Committees, and Audit Quality on Tax Avoidance: An Empirical Study of Non-Financial Firms listed on the Indonesia Stock Exchange from 2013-2016. JCAE Symposium 2018.

Shackelford, D.A., Shevlin, T. 2001. Empirical tax research in accounting. J. Account. Econ. 31 (13), 321-387.

Shan, Y.G. 2013. Can internal governance mechanisms prevent asset appropriation? Examination of type I tunneling in China. Corp. Gov. Int. Rev. 21 (3), 225-241.

Shleifer, A., Vishny, R.W. 1994. Politicians and firms. Q. J. Econ. 109 (4), 995-1025.

Suchman, M.C. 1995. Managing legitimacy: strategic and institutional approaches. Academy of Management Review. Vol. 20 No. 3, pp. 571610.

Sugiharto, and Sari, R.C. 2014. Tunneling dan Corporate Governance. Gadjah Mada University Press.

Sugiyono. 2014. Metode Penelitian Bisnis. Bandung: Alfabeta.

Tang, T. 2016. Privatization, tunneling, and tax avoidance in Chinese SOEs. Asian Review of Accounting Vol. 24 No. 3, 2016 pp. 274-294

Tang, T. and Firth, M. 2011. Can book-tax differences capture earnings management and tax management? Empirical evidence from China. The International Journal of Accounting, Vol. 46 No. 2, pp. $175-204$. 
ILUSTRASI TABEL

Tabel 1. Statistik Deskriptif.

\begin{tabular}{|l|l|l|l|l|l|}
\hline Variabel & $\mathrm{N}$ & Mean & Maximum & Minimum & Std.Dev \\
\hline TA (ETR) & 423 & 0.2493641 & 0.971211 & -2.052633 & 0.2174151 \\
\hline TA (BTD) & 423 & 0.0024019 & 0.6828201 & -0.170578 & 0.0482689 \\
\hline Family & 423 & 0.4567286 & 0.9825 & 0 & 0.3233293 \\
\hline Foreign & 423 & 0.1324426 & 0.9250 & 0 & 0.2796957 \\
\hline Government & 423 & 0.0525608 & 0.9002 & 0 & 0.1845442 \\
\hline MLS & 423 & 0.2529551 & 1 & 0 & 0.4352202 \\
\hline Komind & 423 & 0.4140369 & 0.8333333 & 0.2857143 & 0.0983245 \\
\hline BIG4 & 423 & 0.4326241 & 1 & 0 & 0.4960264 \\
\hline Size & 423 & $1.34 \mathrm{e}+07$ & $3.52 \mathrm{e}+08$ & 49420 & $3.61 \mathrm{e}+07$ \\
\hline Profit & 423 & 0.0762912 & 0.7160259 & 0.0002818 & 0.0779174 \\
\hline Leverage & 423 & 0.4273289 & 1.947497 & 0.0665323 & 0.2162239 \\
\hline PPE & 423 & 0.3393488 & 0.8715653 & 0.000325 & 0.2072018 \\
\hline
\end{tabular}

Tabel 2. Pemilihan Metode Regresi Data Panel.

\begin{tabular}{|l|l|l|l|l|l|}
\hline $\begin{array}{l}\text { Model } \\
\text { Penelitian }\end{array}$ & $\begin{array}{l}\text { Variabel } \\
\text { Dependen }\end{array}$ & Uji Chow & Uji LM & Uji Hausman & Simpulan \\
\hline Mode1 1 & TA (ETR) & 0.0000 & 0.0000 & 0.0000 & Fixed effect \\
\cline { 2 - 6 } & TA (BTD) & 0.0000 & 0.0000 & 0.0442 & Fixed effect \\
\hline Mode1 2A & TA (ETR) & 0.0000 & 0.0000 & 0.0002 & Fixed effect \\
\cline { 2 - 6 } & TA (BTD) & 0.0000 & 0.0000 & 0.1446 & Random effect \\
\hline Mode1 2B & TA (ETR) & 0.0000 & 0.0000 & 0.0005 & Fixed effect \\
\cline { 2 - 6 } & TA (BTD) & 0.0000 & 0.0000 & 0.0708 & Random effect \\
\hline Mode1 2C & TA (ETR) & 0.0000 & 0.0000 & 0.0000 & Fixed effect \\
\cline { 2 - 6 } & TA (BTD) & 0.0000 & 0.0000 & 0.0907 & Random effect \\
\hline
\end{tabular}

Tabel 3. Hasil Regresi Model Penelitian 1. 


\begin{tabular}{|l|l|l|l|l|}
\hline Variabel & \multicolumn{2}{|l|}{ ETR } & \multicolumn{2}{l|}{ BTD } \\
\hline & Coef & $\mathrm{P}>|\mathrm{t}|$ & Coef & $\mathrm{P}>|\mathrm{t}|$ \\
\hline Family & -.0660915 & 0.000 & .0278065 & 0.000 \\
\hline Foreign & -.2070381 & 0.000 & .029768 & 0.008 \\
\hline Government & -.1951051 & 0.000 & .0786972 & 0.000 \\
\hline Size & .0921494 & 0.000 & .0030047 & 0.000 \\
\hline Profit & -.8165633 & 0.000 & .1727472 & 0.000 \\
\hline Leverage & -.1787115 & 0.000 & -.0115068 & 0.003 \\
\hline PPE & -.0812251 & 0.000 & .0182747 & 0.024 \\
\hline Cons & .4774362 & 0.000 & -.0343334 & 0.000 \\
\hline Prob>F & 0.0000 & & 0.0000 & \\
\hline
\end{tabular}

Tabel 4. Hasil Regresi Model Penelitian 2A.

\begin{tabular}{|c|c|c|c|c|}
\hline Variabel & \multicolumn{2}{|l|}{ ETR } & \multicolumn{2}{|l|}{ BTD } \\
\hline & Coef & $P>|t|$ & Coef & $P>|z|$ \\
\hline Family & -.0822782 & 0.000 & .0209007 & 0.017 \\
\hline Foreign & -.2344271 & 0.000 & .0113136 & 0.238 \\
\hline Government & -.1959803 & 0.000 & .0233713 & 0.039 \\
\hline MLS & -.2999251 & 0.000 & .0258696 & 0.115 \\
\hline Family*MLS & .7305882 & 0.000 & -.0567045 & 0.161 \\
\hline Foreign*MLS & .6390878 & 0.001 & -.0433713 & 0.285 \\
\hline Government ${ }^{*}$ MLS & \multicolumn{4}{|l|}{ Ommited } \\
\hline Size & .0930265 & 0.000 & -.0003773 & 0.698 \\
\hline Profit & -.8361685 & 0.000 & .1256481 & 0.000 \\
\hline Leverage & -.1824783 & 0.000 & -.0054481 & 0.478 \\
\hline PPE & -.0811428 & 0.000 & .0078412 & 0.247 \\
\hline cons & .4972073 & 0.000 & -.0225851 & 0.003 \\
\hline Prob $>F$ & \multicolumn{2}{|l|}{0.0000} & \multicolumn{2}{|l|}{0.0000} \\
\hline R-squared & \multicolumn{2}{|l|}{0.2213} & \multicolumn{2}{|l|}{0.1660} \\
\hline
\end{tabular}

Tabel 5. Hasil Regresi Model Penelitian 2B. 


\begin{tabular}{|l|l|l|l|l|}
\hline Variabel & \multicolumn{2}{|l|}{ ETR } & \multicolumn{2}{l|}{ BTD } \\
\hline & Coef & $\mathrm{P}>|\mathrm{t}|$ & Coef & $\mathrm{P}>|\mathrm{z}|$ \\
\hline Family & -.0710385 & 0.001 & .0137858 & 0.052 \\
\hline Foreign & -.2190041 & 0.000 & .0052892 & 0.521 \\
\hline Government & -.1655414 & 0.000 & .0157595 & 0.117 \\
\hline Komind & -.0298002 & 0.870 & -.0097196 & 0.766 \\
\hline Family ${ }^{*}$ Komind & .0768709 & 0.706 & .0091873 & 0.848 \\
\hline Foreign`Komind & .3325949 & 0.254 & -.0193506 & 0.715 \\
\hline Government ${ }^{\star K o m i n d ~}$ & -.0419784 & 0.812 & -.0024299 & 0.965 \\
\hline Size & .0916102 & 0.000 & -.0006537 & 0.493 \\
\hline Profit & -.8155616 & 0.000 & .1267164 & 0.000 \\
\hline Leverage & -.1919962 & 0.000 & -.0022785 & 0.770 \\
\hline PPE & -.0766847 & 0.000 & .009566 & 0.158 \\
\hline Cons & .4832424 & 0.000 & -.019261 & 0.005 \\
\hline Prob>F & 0.0000 & & 0.0000 & \\
\hline
\end{tabular}

Tabel 6. Hasil Regresi Model Penelitian 2C. 


\begin{tabular}{|l|l|l|l|l|}
\hline Variabel & \multicolumn{2}{|l|}{ ETR } & \multicolumn{2}{l|}{ BTD } \\
\hline & Coef & $\mathrm{P}>|\mathrm{t}|$ & Coef & $\mathrm{P}>|\mathrm{z}|$ \\
\hline Family & -.0042178 & 0.494 & .0128001 & 0.130 \\
\hline Foreign & -.0774497 & 0.000 & .0189596 & 0.116 \\
\hline Government & -.2015293 & 0.000 & .0188807 & 0.110 \\
\hline BIG 4 & .4340578 & 0.000 & -.0103115 & 0.294 \\
\hline Family*BIG 4 & -.4229512 & 0.000 & .0064052 & 0.675 \\
\hline Foreign*BIG 4 & -.7347276 & 0.000 & -.013339 & 0.441 \\
\hline Government*BIG 4 & -.8127256 & 0.000 & -.0074009 & 0.706 \\
\hline Size & .0938675 & 0.000 & .0010078 & 0.345 \\
\hline Profit & -.8207938 & 0.000 & .1299528 & 0.000 \\
\hline Leverage & -.1976149 & 0.000 & -.0070107 & 0.357 \\
\hline PPE & -.106541 & 0.000 & .0062224 & 0.355 \\
\hline cons & .4157517 & 0.000 & -.0129413 & 0.083 \\
\hline Prob>F & 0.0000 & & 0.0000 & \\
\hline R-squared & 0.2247 & & 0.1891 & \\
\hline
\end{tabular}

